\title{
Application of Group Technology in a Production of Cardboard Packaging ANd Printed PAPERS
}

\author{
Jovan Pervaz, Ilija Cosic, Dusan Sormaz, Milovan Lazarevic, \\ Nenad Simeunovic \& Nemanja Sremcev
}
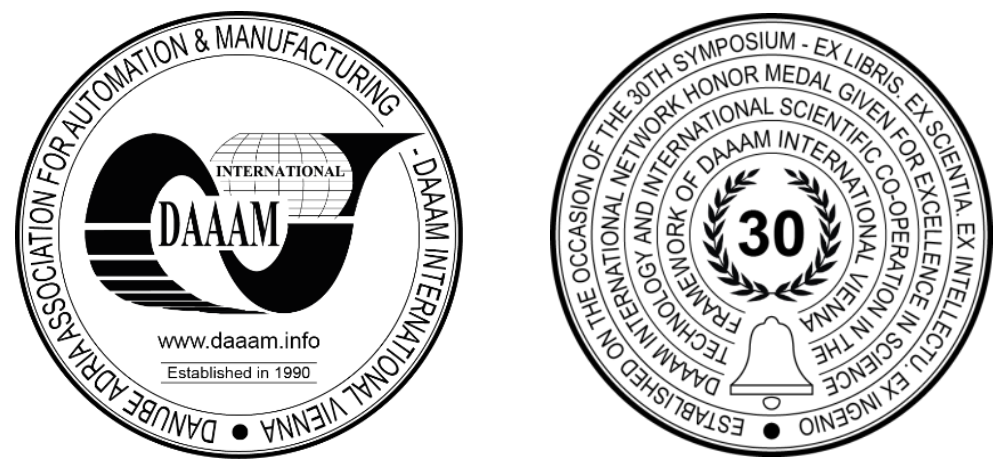

This Publication has to be referred as: Pervaz, J[ovan]; Cosic, I[lija]; Sormaz, D[usan]; Lazarevic, M[ilovan]; Simeunovic, N[enad] \& Sremcev, N[emanja] (2019). Application of Group Technology in a Production of Cardboard Packaging and Printed Papers, Proceedings of the 30th DAAAM International Symposium, pp.0348-0352, B. Katalinic (Ed.), Published by DAAAM International, ISBN 978-3-902734-22-8, ISSN 1726-9679, Vienna, Austria

DOI: 10.2507/30th.daaam.proceedings.046

\begin{abstract}
This paper analyses the possibility of using group technology (GT) in printed packaging production in the graphic industry. The method of grouping that was used is based on the technological processes analysis of products and their pathways through the production system (Production Flow Analysis - PFA). Using this method, after recording all the paths of products through the production system, the diagram was recorded. A total of 1600 different products were analyzed and a total of 37 paths through the production were recorded. Products with the same or similar paths were shaped to form the basis for the formation of cells and virtual cells. Furthermore, times in the production for 5 main product groups were recorded and lead times and total processing times were calculated. For further research, the simulation model in Simio will be made, which will be used to test the results as well as show new alternatives for the improvement of the system.
\end{abstract}

Keywords: Group Technology; Graphic industry; Manufacturing cells; Printing and packaging

\section{Introduction}

The group philosophy has been developed as an approach in production system design, organization, system management, material handling, material processing, etc [1], [2]. It is a method of organizing a production system into such organizational units known as cells. A cell is a set of similar products or parts thereof, a set of machines, a set of means of labour, and a set of labourers necessary to carry out the production process of a given set, at a certain time and to certain parameters. PFA methodology is a set of steps that allows companies to move from production-oriented to processes, to production directed to a product using Group Technology [3], [4]. The process of grouping is carried out in two main phases:

- Analysis of flows in the production system

- Analysis of groups 
The research conducted in this paper represents an effort towards the successful implementation of the group technology concept into the graphic industry company. The introduction of the group technology strategy into the production system is based on successfully dealing with the technical capabilities of the company on one hand and the needs and wishes of customers on the other [5]-[7]. To achieve this goal, the application of group technology and production flow analysis has been proposed. The group technology implementation providing better control of the production processes and is applied towards achieving optimal use of capacities and flexibility of the production system [8]-[10].

The remainder of this paper is organized as follows. In Section 2, we review the relevant literature. In Section 3, we describe our case study in the graphic industry and analysis of data collected. While Section 4 represents the conclusions of the conducted research and plans for further activities.

\section{Literature review of group technology}

Improving profit without increasing the sale price can be only done by minimizing the manufacturing cost of the product [11] and reducing losses during production [12]. In managing a successful improvement of the production process, an array of workable alternatives for improvement must be identified before the final selection decision is made [13], [14]. Group technology is a method of organization for factories in which the machine tools, other processing facilities, and people are divided into groups. Each group completes all the parts it makes, at the processing stage at which operates [15], [16]. Grouping of parts can be achieved in several ways. One way is finding similarities in part geometry, using classification and coding system $(C \& C)$, although this method is not always the most suitable. Burbidge indicates a few reasons that make this method unsatisfactory [17]:

- C\&C system does not group machines

- it tends to group parts made of different material, size, surface quality and

- it is time-consuming and complex

Another method of grouping can be done using part drawings which is known as the visual inspection method. This method becomes hardly practical with an increasing number of parts [18]. Also, part group creation can be done by finding the same processing technology steps that are shared by parts or products [19], [20]. Parts/products that have the same or similar technological operations could be grouped. This method is known as Production Flow Analysis (PFA) which has been developed by Burbidge [21]. PFA consists of several phases which include an analysis of material flow in the production system, forming part families and machine groups, analysis of material flows within cells and analysis of tools concerning the setup time reduction criteria.

Analysis of flows in the production system consists of several steps:

- Analysis of the current flows - determining the flow on the input-output relation for all parts of the production program

- Flowchart design - design of the flowchart using a frequency chart in a way that the logical schedule of the department' $\mathrm{s}$ all paths from the chart are entered and their direction indicated. Also, it should indicate the number of parts passing through a defined path between two departments

- Simplification of the flowchart - there is a high likelihood that a flowchart that was generated upon the real system is very complex, which initiated the need for simplification of the flows. Flowchart simplification can be performed using these methods:

- department combination

- certain types of processing system allocation and

- the elimination of a particular type of work that creates specific difficulties to achieve the ultimate form of flow suitable for analysis of groups

\section{Case study of graphic industry}

For the purpose of the research graphic industry company was chosen. The subject of analysis is offset printing and cardboard packaging production in a company that currently operates according to a shop-floor process layout. Observed enterprise is engaged in the production of cardboard and paper packaging production for other production companies, with an annual production of over 3.500 different products, of which 1600 products were analysed in this research all over the period of half-year. Considering the huge number of different products and possible paths through the production process, the PFA methodology was chosen as the research method. Based on the given methodology and program application, the product paths were recorded, necessary data were generated and cells were created.

\subsection{Production program}

Production program consists of seven product groups: cardboard boxes, corrugated cardboard boxes, labels/medical leaflets, paper wrapping for women's socks, paper wrapping with hot foil stamping for women's socks, cardboard boxes glued in 3 points and cardboard boxes glued in 4 points. 
Considering that cardboard boxes glued in 3 or 4 points only differ in the last phase of the production, main product groups are:

- Cardboard boxes

- Corrugated cardboard boxes

- Labels/medical leaflets

- Paper wrapping for women's socks and

- Paper wrapping with hot foil stamping for women's socks

\subsection{Material flow analysis}

Production takes place through phases of printing, cutting, laminating, foil stamping, die-cutting, gluing, quality control and packaging. The whole product assortment is produced on the number of machines shown in Table 1.

\begin{tabular}{|c|c|c|c|}
\hline Machine label & Machine name & Machine label & Machine name \\
\hline $\mathrm{A}$ & Offset printing machine - Roland 705 & $\mathrm{G}$ & Gluing machine - Grassi \\
\hline B & Offset printing machine - Heidelberg & $\mathrm{H}$ & Gluing machine - Hoson \\
\hline $\mathrm{C}$ & UV varnishing machine & I & Laminating machine \\
\hline $\mathrm{D}$ & Die cutting machine - YAWA & $\mathrm{J}$ & Folding machine \\
\hline E & Die cutting machine - Heidelberg 1050 & $\mathrm{~K}$ & Cutting machine - Wohlenberg \\
\hline $\mathrm{F}$ & Die cutting machine - Heidelberg 780 & $\mathrm{~L}$ & Cutting machine - Polar \\
\hline
\end{tabular}

Table 1. The machine list

The production process starts from the warehouse - S1 where all the material is held. Most of the products start the production process with printing, which is done at machines A and B. Depending on the type of product main later stages are die-cutting and gluing, which are done on the machines D, F, E, and G and H respectively. Only corrugated cardboard boxes require a phase of laminating which is done on machine I. By analysing the movement of subjects of work through the process, the following material flow diagram has been obtained (Figure 1).

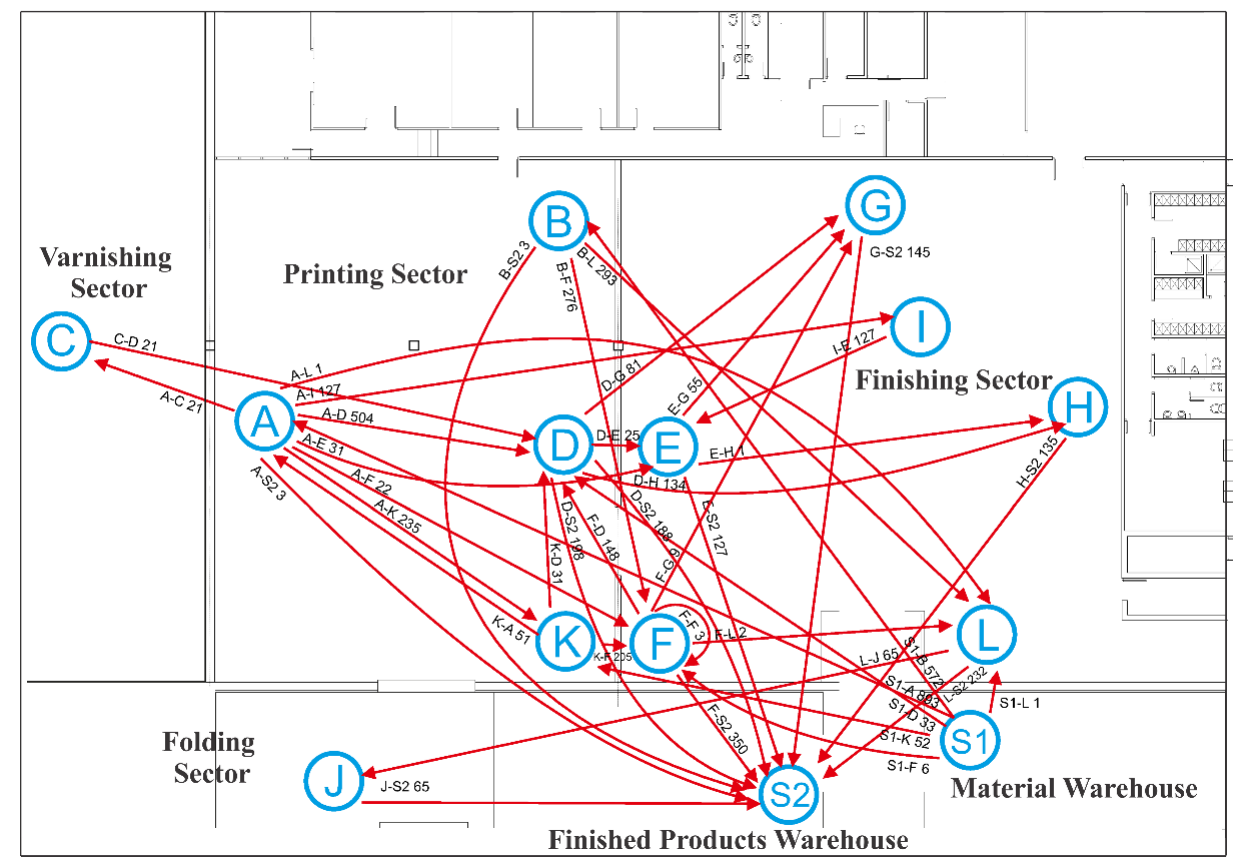

Fig. 1. Material flow network

After analysing all products that were produced (1600 products) in the 6 months' production program and material flowchart was simplified to five main product groups and three independent material flows (Figure 2.). For the analysis of the process of forming cells, 752 representative products of similar product groups were selected. Representatives were selected from five main product types, cardboard boxes, corrugated cardboard boxes, labels/medical leaflets, paper wrapping for women's socks and paper wrapping with hot foil stamping for women's socks. One product type that was excluded from the analysis was self-adhesive labels since many of them were done in one-month period and after that were not produced at all, they are not the standard products of this production system. 


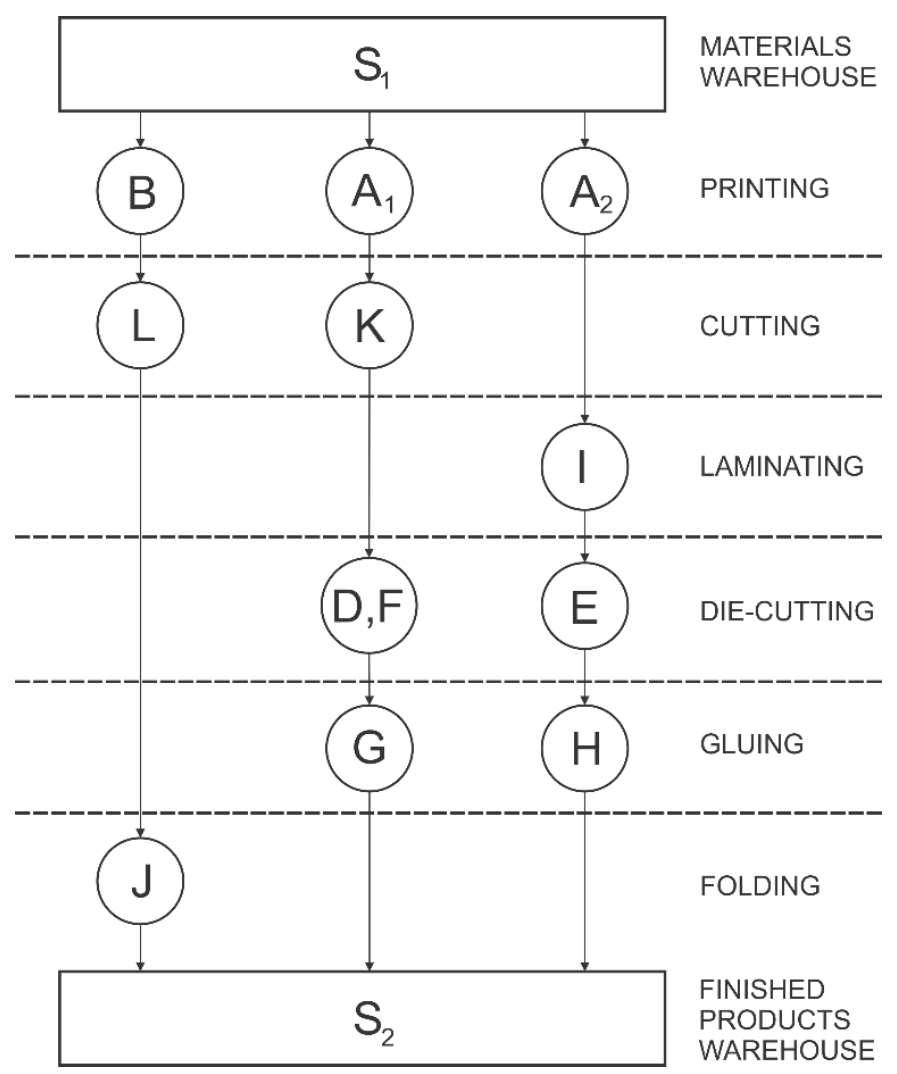

Fig. 2. Simplified system and material flows

Based on the initial material flowchart (Figure 1.), its simplification was carried out to reduce the complexity of flows and eliminate reverse movements. The production system is now organized in such a way that there are three independent flows of materials, more precisely, one manufacturing cell for each material flow. The flow 1 (S1-B-L-J-S2), which contains one printing and one cutting machine is for the manufacture of a product group named labels/medical leaflets. The flow 2 (S1-A1-K-D/F-G-S2), which contains one printing, one cutting, two die-cutting, and one gluing machine is for the manufacture of product groups named cardboard boxes, paper wrapping for women's socks and paper wrapping with hot foil stamping for women's socks. The flow 3 (S1-A2-I-E-H-S2), which contains one printing, one laminating, one die-cutting and one gluing machine is for the manufacture of a product group named corrugated cardboard boxes.

To provide three independent manufacturing cells, another printing machine $\left(\mathrm{A}_{2}\right)$ needs to be purchased, but first and foremost, flows 2 and 3 can share the same printing machine for a while until new machines arrive in the production system. After GT implementation, material flows are separated and set straight. Such a system can be operated in realtime, but less utilization of the equipment is achieved.

\subsection{Production system analysis}

For production times analysis, ten products of each main product category were analysed and times to produce each product were recorded. For each product, date that material has entered the production was starting point, and date that finished good entered finished goods warehouse was the end point. With that information, lead time (LD) was calculated - in days. After that, norms for all the machines in the production system were calculated, and with given quantities of products, total processing time (TPT) was calculated. The ratio between LD and TPT was calculated (Table 2.).

\begin{tabular}{|c|c|c|c|c|}
\hline $\begin{array}{c}\text { Product } \\
\text { groups }\end{array}$ & Product group & $\begin{array}{l}\text { Avg. LD per } \\
\text { Product } \\
\text { (days) }\end{array}$ & $\begin{array}{c}\text { LD/TPT } \\
\text { before }\end{array}$ & $\begin{array}{l}\text { LD/TPT } \\
\text { after GT }\end{array}$ \\
\hline A & Cardboard boxes & 10.80 & 40.31 & 28.59 \\
\hline $\mathrm{B}$ & Corrugated cardboard boxes & 11.80 & 55.35 & 36.02 \\
\hline $\mathrm{C}$ & Labels/medical leaflets & 10.70 & 126.25 & 85.67 \\
\hline $\mathrm{D}$ & Paper wrapping for women's socks and & 9.30 & 21.52 & 16.98 \\
\hline $\mathrm{E}$ & Paper wrapping with hot foil stamping for women's socks & 11.40 & 11.71 & 10.08 \\
\hline & Average for production system: & 10.80 & 51.03 & 34.468 \\
\hline
\end{tabular}

Table 2. The ratio LD/TPT 


\section{Conclusion}

Production flow analysis, based on the existing production technology is a good tool for grouping products with the same or similar paths through the production system. After the grouping process was completed, times of production were recorded for five main products, while the results are as follows:

- Grouping process was done which proves our hypothesis that group technology can be applied in the graphic industry

- Three independent flows of material were made (three manufacturing cells)

- By analysing times, with an average lead time for five main products being 10,80 days, it is obvious that the analysed system is improved with the first stages of group technology implementation. Moreover, the improvement is around $32.5 \%$, from 51.03 to 34.468 times is LD now less than TPT and

- Material flows are straightened, no longer intricate

After analysing the results, the next steps for improvements were made and comparison will be analysed after the full transformation of this production system. Also, for full transformation of the graphic production system cannot only rely on GT and does not end with shop floor transformation. Having that in mind we propose the development of several systems: implementation of ERP and PLM systems, use of software simulations for part group creation, RFID parts tracking, etc. Future research will focus on comparing these two criterions, monitoring parameters of material flow, and its impact on the financial aspect of the business.

\section{References}

[1] Mitrofanov, S. (1959). "Nauchnye Osnovy Gruppovoy Tekhnologii," Lenizdat, Leningrad, Russ.

[2] Burbidge, J. L. (1988). "Period Batch Control," in Computer-Aided Production Management, Berlin, Heidelberg: Springer Berlin Heidelberg, pp. 71-75.

[3] Suzić, N.; Stevanov, B.; Ćosić, I.; Anišić, Z. \& Sremčev, N. (2012). "Customizing products through application of group technology: A case study of furniture manufacturing," Stroj. Vestnik/Journal Mech. Eng., vol. 58, no. 12

[4] Rankov, S.; Cosic, I.; Sormaz, D.; Lazarevic, M. \& Sremcev, N. (2017). "Production Flow Analysis in Textile Production," in XVII International Scientific Conference on Industrial Systems, pp. 44-49.

[5] Sormaz, D.; Arumugam, J. \& Rajaraman, S. (2004). "Integrative process plan model and representation for intelligent distributed manufacturing planning," Int. J. Prod. Res., vol. 42, no. 17, pp. 3397-3417, Sep. 2004.

[6] Sremčev, N.; Ilija, Ć.; Anišić, Z., Lazarević, M. \& Veža, I. (2015). "Algorithm for Product Configurator Development on the Principles of Group Technology," Journal of Trends in the Development of Machinery and Associated Technology, Vol. 19, pp. 81-84

[7] Deuse, J.; Konrad, B. \& Bohnen, F. (2013). "Renaissance of Group Technology: Reducing Variability to Match Lean Production Prerequisites," IFAC Proc. Vol. 46, no. 9, pp. 998-1003

[8] Lazarevic, Dj.; Cosic, I.; Lazarevic, M.; Rikalovic, A. \& Sremcev, N. (2014). “Application of group tools in production of printed and laminated cardboard packaging for total in-process time reduction," in Procedia Engineering, vol. 69

[9] Sremčev, N.; Ćosić, I.; Anišić, Z.; Lazarević, M. \& Gechevska, V. (2015). "Procedure phases for configuration system development," in Annals of DAAAM and Proceedings of the International DAAAM Symposium

[10] Zelenovic, D.; Cosic, I.; Sormaz, D. \& Sisarica, Z. (1987). "Approach to the Design of More Effective Production Systems.," Int. J. Prod. Res., vol. 25, no. 1, pp. 3-15

[11] Klašnja, N.; Sremčev, N.; Vukelić, Dj.; Simeunović, N. \& Lazarević, M. (2019). “Optimization of Cable Harness Assembly Systems Based on Lean Concept Application,” Int. J. Ind. Eng. Manag., vol. 10, no. 1, pp. 115-123

[12] Kumar, S.; Dhingra, A. K. \& Singh, B. (2018). "Process improvement through Lean-Kaizen using value stream map: a case study in India," Int. J. Adv. Manuf. Technol., vol. 96, no. 5-8, pp. 2687-2698

[13] Low, S. N.; Kamaruddin, S. \& Abdul Azid, I. (2015). "Improvement process selection framework for the formation of improvement solution alternatives," Int. J. Product. Perform. Manag., vol. 64, no. 5, pp. 702-722

[14] Nwabueze, U. (2012). "Process improvement: the case of a drugs manufacturing company," Bus. Process Manag. J., vol. 18 , no. 4 , pp. 576-584

[15] Ham, I. (1976). "Introduction to group technology", Society of Manufacturing Engineers, pp. 53

[16] Burbidge, J. L. (1975). “The Introduction of Group Technology," Halsted Press

[17] Burbidge, J. L. (1996). "The first step in planning group technology," Elsevier

[18] Sremcev, N.; Cosic, I.; Suzic, N. \& Stevanov, B. (2012). "Application of PLM systems in group technology approach," in 23rd DAAAM International Symposium on Intelligent Manufacturing and Automation

[19] Dekkers, R. (2018). "Group technology: Amalgamation with design of organisational structures," Int. J. Prod. Econ., vol. 200, pp. 262-277

[20] Yang M. S. \& Yang, J. H. (2008). "Machine-part cell formation in group technology using a modified ART1 method," Eur. J. Oper. Res., vol. 188, no. 1, pp. 140-152

[21] Burbidge, J. L. (1963). “Production flow analysis,” Prod. Eng., vol. 42, no. 12, pp. 742-752 